\title{
Life Science Professional Societies Expand Undergraduate Education Efforts
}

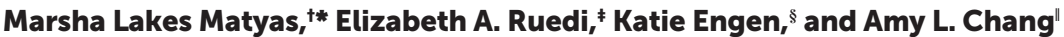 \\ ${ }^{\dagger}$ Education Office, American Physiological Society, Bethesda, MD 20814; ”Education and \\ Professional Development, Genetics Society of America, Bethesda, MD 20814; `Education \\ Foundation, American Society for Plant Biology, Rockville, MD 20855; "Education, American \\ Society for Microbiology, Washington, DC 20036
}

\begin{abstract}
The Vision and Change in Undergraduate Biology Education reports cite the critical role of professional societies in undergraduate life science education and, since 2008 , have called for the increased involvement of professional societies in support of undergraduate education. Our study explored the level of support being provided by societies for undergraduate education and documented changes in support during the Vision and Change era. Society representatives responded to a survey on programs, awards, meetings, membership, teaching resources, publications, staffing, finances, evaluation, and collaborations that address undergraduate faculty and students. A longitudinal comparison group of societies responded to surveys in both 2008 and 2014. Results indicate that life science professional societies are extensively engaged in undergraduate education in their fields, setting standards for their discipline, providing vetted education resources, engaging students in both research and education, and enhancing professional development and recognition/ status for educators. Societies are devoting funding and staff to these efforts and engaging volunteer leadership. Longitudinal comparison group responses indicate there have been significant and quantifiable expansions of undergraduate efforts in many areas since 2008. These indicators can serve as a baseline for defining, aligning, and measuring how professional societies can promote sustainable, evidence-based support of undergraduate education initiatives.
\end{abstract}

\section{INTRODUCTION/BACKGROUND}

Scientific disciplinary societies play important roles in setting standards for education as well as science in their fields. Wei et al. (2012) call the leadership of disciplinary societies "one of the most powerful forces in shaping the culture and priorities in a discipline" (p. 882). Such organizations serve as both a repository for the history of a given discipline and the unifying catalyst for its advancement. Societies are motivated and poised to prepare future practitioners, relying on goals that lead to disciplinary advancement. Member-based leadership prioritizes society programs and resources that will benefit current and future members. National initiatives to reform science education have recognized this influence and have uniformly called for scientific societies to be part of major change initiatives at every educational level (Weidman et al., 2001; National Academy of Sciences, National Academy of Engineering, and Institute of Medicine, 2007, 2010, 2014; American Association for the Advancement of Science [AAAS], 2010, 2011b, 2015b; President's Council of Advisors on Science and Technology, 2012; American Association of Physics Teachers [AAPT], 2013; Next Generation Science Standards, 2013; Mercier, 2015). Recent national efforts to reform undergraduate life science education have consistently called for the active involvement of professional societies. The 2010 report Vision and Change in Undergraduate Biology: A Call to Action called on societies to "increase awareness of the critical nature of undergraduate biology education, regularly disseminate science education research, and
Erin L. Dolan, Monitoring Editor Submitted January 11, 2016; Revised October 26, 2016; Accepted October 27, 2016

CBE Life Sci Educ March 1, 2017 16:ar5 DOI:10.1187/cbe.16-01-0019

Potential conflict of interest: The authors are employed by professional societies that are the target audience of the study. The authors provided responses for the study survey for their respective societies. One of the authors is a staff member at Genetics Society of America, which is an editorial partner with CBE-Life Sciences Education.

*Address correspondence to: Marsha Lakes Matyas (mmatyas@athe-aps.org)

(c) 2017 M. L. Matyas et al. CBE-Life Sciences Education $\odot 2017$ The American Society for Cell Biology. This article is distributed by The American Society for Cell Biology under license from the author(s). It is available to the public under an Attribution-Noncommercial-Share Alike 3.0 Unported Creative Commons License (http://creativecommons.org/licenses/ by-nc-sa/3.0).

"ASCB $®$ " and "The American Society for Cell Biology $\circledR^{\prime \prime}$ are registered trademarks of The American Society for Cell Biology. 
contribute to the professional development of their members" (AAAS, 2010, p. 11). In 2012, the National Research Council (NRC) recommended that professional societies support faculty in improving undergraduate education by helping faculty to adopt evidence-based teaching practices (Singer et al., 2012). Clearly, the current nationwide initiatives to transform undergraduate life science education envision a clear and pivotal role for disciplinary societies (AAPT, 2013).

\section{Society Responses}

Fulfilling this role requires commitment by society leadership and dedication of society resources. Within the life sciences this is a complex process; unlike many of the physical science disciplines, no single organization represents the wide diversity of life science fields. Of the 200 societies affiliated with the AAAS, at least $64(32 \%)$ are life science societies (AAAS, 2015a). Thus, engaging professional societies in undergraduate education reform requires the collective efforts of leadership and staff across dozens of life science professional societies (LSPS). Similarly, the diversity of LSPS in terms of disciplinary scope, organizational focus, and membership size and characteristics (Musante and Potter, 2012) hinders the development of standardized norms for research, membership, and education across all life science fields.

LSPS efforts to influence undergraduate education have originated from both individual organizations and collaborative groups. LSPS frequently include promotion of education in their mission statements. Many also work to improve members' pedagogical effectiveness based upon education research and to increase both the recognition of effective teaching and its commensurate rewards. Most LSPS have had a long-term focus on undergraduate education. Matyas analyzed presentations and results of a brief survey conducted in 2008 of 15 LSPS concerning their current and planned activities in support of undergraduate education (Matyas, 2008). The LSPS described diverse initiatives and programs (described later), and many set goals to raise the visibility and importance of teaching among researchers in their fields; increase undergraduate student affiliation with and understanding of their fields; develop standards and/or materials for a 21st-century curriculum, provide resources based on these standards, and prepare faculty to teach them; and promote collaboration among stakeholders.

A number of professional society collaborations to support undergraduate life science education have developed with varying purposes and impacts:

- The Coalition for Education in the Life Sciences (CELS) provided a mechanism for organizations to discuss common goals related to undergraduate life science education in the 1990s. CELS produced multiple reports on both undergraduate education and the role of LSPS in promoting the importance of teaching faculty (NRC, 2003).

- The BioSciEd Net (BEN) Collaborative (www.biosciednet .org) began in the late 1990s and provided an opportunity for a group of life science societies' staff and volunteer leaders to collaborate on the development of an online search portal for more than 25 society digital libraries (AAAS, 2011a). The BEN portal continues to offer free access to more than 18,000 reviewed teaching resources on more than 75 major life science topics.
- The Disciplinary Societies and Education Associations (DSEA) Alliance provides informal opportunities for networking around topics of common concern related to science, technology, engineering, and mathematics (STEM) education. This group includes representatives from all STEM disciplines and does not, therefore, offer a focused network for the life science community (Project Kaleidoscope, 2015).

It should be noted that STEM reform is much broader than the life science disciplines. Efforts for reform are active in many STEM fields, including geosciences, engineering, chemistry, and physics (Hilborn et al., 2003; Macdonald et al., 2004; American Society for Engineering Education, 2013; Sawyer and Alper, 2014). Each field contributes to our understanding of effective teaching practices and STEM professional development.

\section{Formation of PSALSE}

In 2013, AAAS convened a second Vision and Change (V\&C) conference to chronicle the changes and initiatives launched since the first Vision and Change report (AAAS, 2011b, 2015b). During the meeting, participants again called for support and leadership from the LSPS. Soon after the conference, the American Institute of Biological Sciences (AIBS) organized a 2013 meeting of 18 LSPS representatives to discuss the V\&C conference outcomes and explore ways to achieve greater impact on undergraduate education through collaboration. Initial discussions focused on identifying the primary leverage points where LSPS could influence change in undergraduate life science education. The group also felt it was important to share this information with others involved in undergraduate education reform (e.g., other life science societies; funding agencies; undergraduate educators and administrators; and LSPS leadership, staff, and members).

In April 2014, the group agreed to function as an open alliance called Professional Societies Alliance for Life Science Education (PSALSE; www.psalse.org) with the express purpose of meeting regularly to network, share ideas and resources, and discuss possible collaborations that might emerge from their mutual interests to increase their collective impacts (Table 1). In light of the V\&C conference call for action by LSPS, the group elected to begin documenting undergraduate initiatives by PSALSE member organizations. The collaborators used the matrix that was developed in 2008 (Matyas, 2008) as a starting point to develop a more comprehensive survey.

The purposes of the current study are to provide 1) information on the current undergraduate-focused activities and initiatives of a diverse group of LSPS and 2) a comparison of the activities and initiatives of a subset of those LSPS before and after the initial years of the V\&C initiative.

\section{METHODS \\ 2008 Data}

As described earlier, information was gathered in November 2008 via presentations and a brief survey from 15 LSPS concerning their current activities in support of undergraduate education (Matyas, 2008). Data collection was part of a meeting of LSPS leadership to plan future activities for undergraduate education in their disciplines. On the final day of the meeting, each life science professional society leader presented goals, 
TABLE 1. Life science organizations responding to 2008 and 2014 surveys and participating in PSALSE

\begin{tabular}{|c|c|c|c|}
\hline \multirow[b]{2}{*}{ Scientific societies } & \multicolumn{2}{|c|}{ Respondents } & \multirow[b]{2}{*}{ PSALSE participant } \\
\hline & 2008 & 2014 & \\
\hline American Association for the Advancement of Science (AAAS) & $\mathrm{X}$ & & $\mathrm{X}$ \\
\hline American Institute of Biological Sciences (AIBS) & $\mathrm{X}$ & $\mathrm{X}$ & $\mathrm{X}$ \\
\hline American Physiological Society (APS) & $\mathrm{X}$ & $\mathrm{X}$ & $\mathrm{X}$ \\
\hline American Society for Biochemistry and Molecular Biology (ASBMB) & $\mathrm{X}$ & $\mathrm{X}$ & $\mathrm{X}$ \\
\hline American Society for Bone and Mineral Research & & $\mathrm{X}$ & \\
\hline American Society for Cell Biology (ASCB) & $\mathrm{X}$ & $\mathrm{X}$ & $\mathrm{X}$ \\
\hline American Society for Investigative Pathology (ASIP) & & $\mathrm{X}$ & \\
\hline American Society for Microbiology (ASM) & $\mathrm{X}$ & $\mathrm{X}$ & $\mathrm{X}$ \\
\hline American Society for Pharmacology and Experimental Therapeutics (ASPET) & & $\mathrm{X}$ & $\mathrm{X}$ \\
\hline American Society of Human Genetics (ASHG) & & $\mathrm{X}$ & $\mathrm{X}$ \\
\hline American Society of Plant Biologists (ASPB) & $\mathrm{X}$ & $\mathrm{X}$ & $\mathrm{X}$ \\
\hline American Society of Primatologists & & $\mathrm{X}$ & \\
\hline Anaerobe Society of the Americas & & $\mathrm{X}$ & \\
\hline Association for the Sciences of Limnology and Oceanography & & $\mathrm{X}$ & $\mathrm{X}$ \\
\hline Biophysical Society & $\mathrm{X}$ & $\mathrm{X}$ & \\
\hline BioQUEST Curriculum Consortium & & & $\mathrm{X}$ \\
\hline Botanical Society of America (BSA) & $\mathrm{X}$ & $\mathrm{X}$ & $\mathrm{X}$ \\
\hline Ecological Society of America (ESA) & $\mathrm{X}$ & $\mathrm{X}$ & $\mathrm{X}$ \\
\hline Genetics Society of America (GSA) & $\mathrm{X}$ & $\mathrm{X}$ & $\mathrm{X}$ \\
\hline Human Anatomy and Physiology Society (HAPS) & & $\mathrm{X}$ & $\mathrm{X}$ \\
\hline National Association of Biology Teachers (NABT) & $\mathrm{X}$ & $\mathrm{X}$ & $\mathrm{X}$ \\
\hline Partnership for Undergraduate Life Science Education (PULSE) & & $\mathrm{X}$ & $\mathrm{X}$ \\
\hline Poultry Science Association & & $\mathrm{X}$ & \\
\hline Project Kaleidoscope & & $\mathrm{X}$ & \\
\hline Society for Behavioral Neuroendocrinology & & $\mathrm{X}$ & \\
\hline Society for Conservation Biology & & & $\mathrm{X}$ \\
\hline Society for Developmental Biology (SDB) & & $\mathrm{X}$ & $\mathrm{X}$ \\
\hline Society for Economic Botany & & & $\mathrm{X}$ \\
\hline Society for Freshwater Science & & $\mathrm{X}$ & \\
\hline Society for Integrative and Comparative Biology (SICB) & $\mathrm{X}$ & $\mathrm{X}$ & $\mathrm{X}$ \\
\hline Society for Neuroscience (SfN) & $\mathrm{X}$ & & $\mathrm{X}^{\mathrm{a}}$ \\
\hline Society for the Study of Evolution (SSE) & $\mathrm{X}$ & $\mathrm{X}$ & $\mathrm{X}$ \\
\hline Society of Toxicology & & $\mathrm{X}$ & $\mathrm{X}$ \\
\hline Southwestern Association of Naturalists & & $\mathrm{X}$ & \\
\hline Total & 15 & 29 & 24 \\
\hline
\end{tabular}

${ }^{\mathrm{a}}$ Faculty for Undergraduate Neuroscience (FUN).

strategies, and plans for future activities. Overall, the 2008 meeting provided a "snapshot" of LSPS undergraduate activities and plans for their maintenance and/or expansion. Data are reprinted here with permission.

\section{Data}

PSALSE discussions in 2013 and 2014 led to the development of a follow-up survey to take a second snapshot of current activities of LSPS. A draft survey was reviewed by PSALSE participants representing multiple LSPS. The final survey asked about education personnel (paid staffing and volunteer education leadership), undergraduate award programs, scientific and educational meetings, membership leadership benefits for undergraduate faculty and students, teaching resources, publications, financing of education programs, collaborations with other organizations, and program evaluation strategies. The 2014 survey included more questions than did the 2008 survey, and some 2008 questions were edited for the 2014 survey.
For example, questions in 2014 included more detail on technology developments (social media, digital libraries, and online communication) and educational meeting types (workshops and conferences). Specific changes are detailed in the tables.

The 2014 survey was administered from August to October 2014 by the American Society for Microbiology via SurveyMonkey (SurveyMonkey, 2015). Invited recipients included the 15 LSPS that provided information in 2008 and additional LSPS identified by PSALSE participants as "life science societies or organizations" (Table 1). These invitations resulted in responses from 26 LSPS. Of the 15 LSPS that provided data in 2008, 13 responded for a subset response rate of $87 \%$. In addition, an open-link invitation was sent to a broader list of LSPS by AIBS, resulting in an additional three respondents. Overall, 29 LSPS responded. In most cases, the survey was sent to an education staff member or the society executive director. In a few cases, the education committee chair was the most direct contact. The 
survey directions assured respondents that the answers would be shared only in the aggregate; this reduced concerns about response bias by professional society staff or chairs.

Subsequent to the initial data collection, one additional question was deemed important to be added to the awards and fellowships questions. This question asked whether the society provided awards for undergraduate research (e.g., abstract or poster/oral presentation-based awards). Responses to this question were gathered via email and tallied and are noted in the Results section.

It should be noted that all data are derived from self-reports in response to survey questions about LSPS programs, services, and organizational information; most of this information is publicly available at organizational websites and in society publications. Survey respondents were not the subjects of the study, nor were they providing any personal information; therefore, an IRB approval was not needed (U.S. Department of Health and Human Services, 2016). The raw data from the 2008 survey were published in the original AAAS report (Matyas, 2008). The raw data from the 2014 study are not included here; 2014 data are provided only in the aggregate, without identifying information. Each participating society provided written permission for its name to be listed on the study and for its data to be reported in the aggregate.

Data analysis provided frequencies/percentages for all variables. Separate comparisons were made for the subset of LSPS that completed the survey in both 2008 and 2014 (hereafter referred to as the "longitudinal comparison group"). Because the 2008 and 2014 sample sizes were small and the results were nominal (e.g., "yes" or "no" responses), we used Fisher's exact test of independence to compare the responses (McDonald, 2014).

\section{RESULTS}

As described earlier, responses were received from 13 longitudinal comparison group LSPS and 16 additional LSPS. Most of the LSPS currently participating in PSALSE meetings responded to the 2014 survey. For all results, the full set of 2014 respondents will be described first, followed by a description of changes in the longitudinal comparison group LSPS from 2008 to 2014. Questions and responses are grouped into five major categories that reflect common organization of LSPS programs and activities: awards, fellowships, and grants; meetings; teaching resources and publications; society mission, governance, staffing, budgets, and collaborations; and program evaluation and dissemination. These overlap with the V\&C recommendations for direct student support, educational resource development, education research support, and community engagement, as noted below.

\section{Awards, Fellowships, and Grants}

Society awards, fellowships, and grants provide professional development and recognize excellence in the field. They overlap with the V\&C recommendations for direct student support, education research support, and community engagement. Nearly all of the responding LSPS offer travel grants for undergraduate students to attend scientific meetings, and more than three-quarters offer travel grants specifically for students from groups underrepresented in STEM (Table 2). However, they were about half as likely to offer research fellowships for undergraduate students, including students from underrepresented groups.

Awards for undergraduate faculty to recognize excellence in teaching, mentoring, and/or scientific research in the discipline were more common (56-64\%) than were awards for educational research (32\%) or K-12 and community outreach (24\%).

TABLE 2. Societies sponsoring awards, fellowships, and grants 2008-2014

\begin{tabular}{|c|c|c|c|c|}
\hline \multirow[b]{2}{*}{ Awards, fellowships, and grants } & \multirow{2}{*}{$\begin{array}{l}2014 \\
\text { All respondents (\%) }\end{array}$} & \multicolumn{3}{|c|}{ Comparison group } \\
\hline & & $2008(\%)$ & $2014(\%)$ & $p$ \\
\hline Travel grants for undergraduate students to attend scientific meetings & 96 & 27 & 85 & 0.002 \\
\hline Research fellowships for undergraduate students & 52 & 33 & 54 & ns \\
\hline $\begin{array}{l}\text { Research fellowships for undergraduate students from underrepresented populations in } \\
\text { science }\end{array}$ & 32 & & & \\
\hline Awards of excellence for undergraduate faculty in recognition of teaching and/or mentoring & 64 & 53 & 69 & ns \\
\hline $\begin{array}{l}\text { Awards of excellence for undergraduate faculty in recognition of educational research in the } \\
\text { discipline }\end{array}$ & 32 & 0 & 46 & 0.006 \\
\hline $\begin{array}{l}\text { Education fellowships (e.g., in pedagogy, education research, and/or curriculum) for } \\
\text { undergraduate faculty }\end{array}$ & 8 & 0 & 15 & ns \\
\hline Travel grants for undergraduate faculty to attend scientific meetings & 44 & & & \\
\hline $\begin{array}{l}\text { Travel grants for undergraduate faculty from underrepresented populations in science to } \\
\text { attend scientific meetings }\end{array}$ & 44 & & & \\
\hline Travel grants for undergraduate faculty to attend education meetings & 24 & & & \\
\hline Other fellowships, awards, or travel grants for undergraduate students or faculty & 10 & & & \\
\hline
\end{tabular}

${ }^{\text {aNot }}$ available. This question was not included in the 2014 survey. A separate query was sent to the comparison group to generate comparative data. 
Similarly, LSPS travel grants for undergraduate faculty, including those from underrepresented groups, to attend scientific meetings (44\%) were more common than were those to attend education meetings (24\%; Table 2 ).

Longitudinal comparison group responses indicate growth in undergraduate awards, fellowships, and grants. The number of LSPS offering travel grants for undergraduate students more than tripled, with 85\% offering travel grants in 2014 ( $p=$ 0.002). Similarly, the number of LSPS recognizing undergraduate students for excellence in research increased more than threefold (from 20 to $71 \%$ ) ( $p=0.009$ ).

In 2008 , there were no awards of excellence for educational research, but nearly half of the same LSPS offered such awards by 2014 ( $p=0.006)$. We did not, however, see significant increases in the number of LSPS offering awards of excellence for teaching or mentoring (from 53 to 69\%) or fellowships for educational research (from 0 to $15 \%$ ).

\section{Meetings}

Meetings serve many purposes for LSPS. Not only is current scientific research presented, but many LSPS present educational research and offer faculty development workshops. Networking leads to planning for collaborations. In terms of the V\&C recommendations, scientific meetings provide both educational research support and community engagement. In the current study, LSPS included opportunities for both students and faculty members at their regular scientific meetings. The 2014 respondents offered undergraduate students opportunities to present at regular scientific sessions (82\%) and special undergraduate sessions (46\%; Table 3). Education-focused sessions also were very common at their scientific meetings, and satellite meetings often focused on either career development or education issues. Other common venues were LSPS exhibits and/or presentations at education and outreach conferences and undergraduate student conferences, and LSPSsponsored workshops, institutes, or courses on education, including undergraduate education.

There was growth between 2008 and 2014 in some of the types of education events sponsored by the longitudinal comparison group LSPS (Table 3 ). The number including education sessions in their scientific meetings significantly increased during this period from 40 to $92 \%(p=0.005)$. More than $90 \%$ of LSPS dedicated funds and staff to exhibit and/or make presentations at undergraduate conferences and education meetings by 2014, a significant increase from the 2008 response (33\%; $p=0.002)$. The number of societies holding education workshops, institutes, courses or conferences remained steady during this period (62 to $69 \%$ ).

TABLE 3. Societies sponsoring undergraduate education events 2008-2014

\begin{tabular}{|c|c|c|c|c|}
\hline \multirow[b]{2}{*}{ Events } & \multirow{2}{*}{$\begin{array}{l}2014 \\
\text { All respondents (\%) }\end{array}$} & \multicolumn{3}{|c|}{ Comparison group } \\
\hline & & $2008(\%)$ & $2014(\%)$ & $p$ \\
\hline $\begin{array}{l}\text { Scientific meeting that includes sessions highlighting education (e.g., teaching } \\
\text { excellence, pedagogy, scholarship of teaching) }\end{array}$ & 71 & 40 & 92 & 0.005 \\
\hline $\begin{array}{l}\text { Scientific meeting that includes sessions specifically designated for undergraduate } \\
\text { students to present their research }\end{array}$ & 39 & 47 & 62 & ns \\
\hline $\begin{array}{l}\text { Scientific meeting that includes regular sessions for all attendees, including } \\
\text { undergraduates, to present research }\end{array}$ & 82 & & & \\
\hline $\begin{array}{l}\text { Scientific meeting that includes sessions specifically for undergraduate students to } \\
\text { network with scientists }\end{array}$ & 46 & 13 & 46 & ns \\
\hline $\begin{array}{l}\text { Pre- or postconference education workshop (e.g., on pedagogy, scholarly teaching, } \\
\text { curriculum, broadening participation, and/or outreach) at scientific meetings }\end{array}$ & 54 & & & \\
\hline $\begin{array}{l}\text { Pre- or postconference career development workshop (e.g., on publishing, } \\
\text { grantsmanship, and/or work-life balance) at scientific meetings }\end{array}$ & 61 & & & \\
\hline $\begin{array}{l}\text { Exhibits and/or presentations at undergraduate student conferences (e.g., annual } \\
\text { meetings for the Society for Advancement of Native Americans in Science, Council } \\
\text { for Undergraduate Research, and Emerging Research Network, and/or Annual } \\
\text { Biomedical Research Conference for Minority Students) }\end{array}$ & 50 & $33^{\mathrm{a}}$ & 92 & 0.002 \\
\hline $\begin{array}{l}\text { Exhibits and/or presentations at education and outreach conferences (e.g., annual } \\
\text { meetings for the National Association of Biology Teachers, National Science Teacher } \\
\text { Association, Human Anatomy and Physiology Society, Council for Undergraduate } \\
\text { Research, and/or Understanding Interventions that Broaden Participation in Research } \\
\text { Careers) }\end{array}$ & 54 & & & \\
\hline Stand-alone workshops, institutes, and/or courses for undergraduate faculty & 32 & $62^{\mathrm{b}}$ & 69 & ns \\
\hline $\begin{array}{l}\text { Stand-alone workshops, institutes, and/or courses for future faculty interested in } \\
\text { undergraduate education }\end{array}$ & 11 & & & \\
\hline Stand-alone workshops, institutes, and/or courses for undergraduate students & 14 & & & \\
\hline $\begin{array}{l}\text { Stand-alone education conference (e.g., on pedagogy, scholarly teaching, curriculum, } \\
\text { broadening participation, and/or outreach) }\end{array}$ & 25 & & & \\
\hline Other meetings or meeting activities & 25 & & & \\
\hline
\end{tabular}

${ }^{\mathrm{a} A} 2008$ question concerning exhibits combined these two groups of meetings. The 2014 comparative data tallied the percentage of organizations that exhibited at one or both groups of meetings.

${ }^{\text {bThe }} 2008$ data tallied all organizations that held education conferences or summits. The 2014 comparative data tallied the percentage of organizations that had any of the four described types of stand-alone workshops, conferences, or summits. 


\section{Membership}

LSPS membership benefits are generally customized for the target audience, but all provide opportunities for community engagement. In 2014, nearly all LSPS offered discount memberships for undergraduate students (Table 4). Most offered career-planning and development workshops and services (78\%) and job placement services (52\%). Direct services to undergraduates were less frequent, with student clubs or chapters $(37 \%)$ and special interest groups for undergraduate students either online (22\%) or at their meetings (26\%) being the most common activities.

There was significant growth between 2008 (27\%) and 2014 (92\%) in longitudinal comparison group LSPS offering discounted memberships for undergraduate students $(p<0.001)$. Similarly, in 2008, only one LSPS had student clubs or chapters, but by 2014, more than two-thirds sponsored clubs or chapters to engage undergraduate students, representing a significant increase $(p=0.002)$.

\section{Teaching Resources and Publications}

LSPS websites and digital libraries have provided a cost-effective way to distribute information and publications, reducing printing and shipping costs and, in many cases, making materials free to members and often to the public. Nevertheless, the development costs for quality educational materials or curricula remains significant and must be considered by LSPS leadership along with V\&C calls for society-developed curricula. About half of the LSPS responding in 2014 offered peer-reviewed curricular resources and multimedia resources (Table 5), but far fewer offered peer-reviewed disciplinary curricular guidelines. Nearly one-third offered online learning and networking communities for undergraduate faculty, and more than one-quarter offered similar communities for undergraduate students. Most LSPS had a social media presence, posting either regularly or occasionally.

About two-thirds of the longitudinal comparison group offered peer-reviewed or unreviewed curricular resources in both 2008 and 2014 (Table 5), but there was significant growth in the number offering multimedia resources, increasing from 13 to $73 \%$ ( $p=0.002)$. In 2008, online learning and networking communities consisted primarily of listservs and the occasional blog; only 13\% of the 2008 longitudinal comparison group had either a listserv or blog dedicated to teaching, but more than half had a digital library that included teaching resources, many having been developed with support from the National Science Foundation's (NSF) National Science Digital Library program. All of these digital libraries continued to function, and many were transformed into online learning and networking communities by 2014.

In 2014, LSPS were most likely to publish information on education topics through their newsletters or research journals (Table 6). However, a number of LSPS published a peer-reviewed educational or educational research journal of their own or in joint sponsorship with another society. Many published education topics or articles in their newsletters and/or journals on either a regular or occasional basis. Very few published textbooks for undergraduate courses.

There was little change within the longitudinal comparison group in the number publishing a jointly sponsored educational research journal. However, the number publishing education topics or articles in their society newsletters more than doubled during this period, and the number publishing occasional education articles in their research journals more than quadrupled. These increases were not significant, due to the small sample size.

\section{Society Mission, Governance, Staffing, Budgets, and Collaborations}

LSPS vary widely in their staffing, sources of income, and governance structures, but community engagement-encouraging members to take an active role in the society and its programsis common, whether memberships number in the hundreds or tens of thousands. A series of questions asked respondents to describe how undergraduate education is addressed through the LSPS missions, governance, staffing, budgets, and collaborations for education programs. In 2014, LSPS described how

TABLE 4. Society membership activities to support undergraduate education 2008-2014

\begin{tabular}{|c|c|c|c|c|}
\hline \multirow[b]{2}{*}{ Membership activities } & \multirow{2}{*}{$\begin{array}{l}2014 \\
\text { All respondents (\%) }\end{array}$} & \multicolumn{3}{|c|}{ Comparison group } \\
\hline & & $2008(\%)$ & $2014(\%)$ & $p$ \\
\hline Discounted membership for undergraduate students & 89 & 27 & 92 & $<0.0001$ \\
\hline $\begin{array}{l}\text { Discounted membership for undergraduate faculty involved primarily in } \\
\text { teaching (e.g., lecturers, and/or faculty from community colleges or primary } \\
\text { undergraduate institutions) }\end{array}$ & 7 & & & \\
\hline $\begin{array}{l}\text { Discounted membership for future faculty (e.g., graduate students and postdoc- } \\
\text { toral fellows) involved primarily in undergraduate teaching (e.g., teaching } \\
\text { assistants and part-time or temporary lecturers or faculty) }\end{array}$ & 44 & & & \\
\hline $\begin{array}{l}\text { Career planning and development workshops, services, and/or resources (e.g., on } \\
\text { topics such as résumé writing, interviewing, networking, and work-life } \\
\text { balance) }\end{array}$ & 78 & & & \\
\hline Job placement and/or employment services & 52 & & & \\
\hline Student clubs or chapters & 37 & 7 & 69 & 0.002 \\
\hline National Honor Society for undergraduate students & 4 & 7 & 7 & ns \\
\hline Special interest groups for undergraduate students (online only) & 22 & & & \\
\hline Special interest groups for undergraduate students at scientific meetings & 26 & & & \\
\hline Other membership services & 7 & & & \\
\hline
\end{tabular}


TABLE 5. Digital resources offered by societies 2008-2014

\begin{tabular}{|c|c|c|c|c|}
\hline \multirow[b]{2}{*}{ Digital resources } & \multirow{2}{*}{$\begin{array}{c}2014 \\
\text { All respondents (\%) }\end{array}$} & \multicolumn{3}{|c|}{ Comparison group } \\
\hline & & $2008(\%)$ & $2014(\%)$ & $p$ \\
\hline Peer-reviewed curriculum guidelines & 23 & 7 & 31 & ns \\
\hline Peer-reviewed curriculum resources & 50 & 60 & $67^{\mathrm{a}}$ & ns \\
\hline Unreviewed curriculum resources & 38 & & & \\
\hline Peer-reviewed presentations and/or teaching (multimedia) resources & 50 & 13 & $73^{\mathrm{a}}$ & 0.002 \\
\hline Unreviewed presentations and/or teaching (multimedia) resources & 54 & & & \\
\hline Curated lists of undergraduate degree-granting institutions in the discipline & 12 & & & \\
\hline Noncurated lists of undergraduate degree-granting institutions in the discipline & 4 & & & \\
\hline Online learning and networking communities for undergraduate faculty & 31 & $13^{\mathrm{b}}$ & 31 & ns \\
\hline Online learning and networking communities for undergraduate students & 27 & 7 & 31 & ns \\
\hline $\begin{array}{l}\text { Occasional participation and presence in social media (e.g., Facebook, Twitter, } \\
\text { LinkedIn) }\end{array}$ & 35 & & & \\
\hline $\begin{array}{l}\text { Regular participation and presence in social media (e.g., Facebook, Twitter, } \\
\text { LinkedIn) }\end{array}$ & 65 & & & \\
\hline Other digital resources, online communities, or communication practices & 8 & & & \\
\hline Blog & 8 & & & \\
\hline Digital library ${ }^{c}$ & & 53 & N/A & \\
\hline Education website & & 7 & NA & \\
\hline
\end{tabular}

ancludes societies that had either peer-reviewed or non-peer reviewed resources.

bIn 2008, the question summarized those who had teaching listservs or blogs.

cMost 2008 digital libraries transformed to online learning and networking communities by 2014.

they address undergraduate education through their missions and involvement of undergraduate faculty and students in society governance. For nearly half of respondents (48\%), their societies' missions and strategic goals address undergraduate education explicitly. The large majority (81\%) engage undergraduate faculty in society governance and/or committees but are less likely to specifically include community college faculty (33\%), future faculty (e.g., graduate students and postdocs involved in undergraduate teaching; 44\%), or undergraduate students (22\%) in governance (Supplemental Table S1).

Open-ended questions asked about the volunteers and staff who work on education initiatives. Responses indicated that both volunteers and paid staff working in education or outreach positions have job titles that are as varied and unique as each participating organization (Supplemental Table S2). Most LSPS (86\%) have a committee chair charged with education issues, either exclusively or in combination with communication and/ or diversity. In terms of staff, $36 \%$ listed a director's position tasked with education either exclusively or with other responsibilities, and 36\% described a manager/coordinator position devoted to education along with other areas.

In 2014, LSPS were asked to indicate whether there had been changes in the number of full-time staff or full-time staff equivalents dedicated to education initiatives and programs since 2008. Most LSPS (55\%) indicated their staffing had remained the same. Nearly one-third (31\%), however, indicated they had increased the number of full-time staff equivalents dedicated to education initiatives or activities. Only $14 \%$

TABLE 6. Societies sponsoring publications and communications to support undergraduate education 2008-2014

\begin{tabular}{|c|c|c|c|c|}
\hline \multirow[b]{2}{*}{ Publication/communication activities } & \multirow{2}{*}{$\begin{array}{c}2014 \\
\text { All respondents (\%) }\end{array}$} & \multicolumn{3}{|c|}{ Comparison group } \\
\hline & & $2008(\%)$ & $2014(\%)$ & $p$ \\
\hline $\begin{array}{l}\text { Jointly sponsored peer-reviewed education and/or educational research journal } \\
\text { (e.g., CBE_Life Sciences Education sponsored by American Society for Cell Biology } \\
\text { and Genetics Society of America; Biochemistry and Molecular Biology Education } \\
\text { sponsored by the International Union of Biochemistry and Molecular Biology and } \\
\text { John Wiley \& Sons) }\end{array}$ & 12 & 7 & 15 & ns \\
\hline $\begin{array}{l}\text { Society-sponsored peer-reviewed education and/or educational research journal (e.g., } \\
\text { Advances in Physiology Education and Journal of Microbiology and Biology Education) }\end{array}$ & 19 & 27 & 23 & ns \\
\hline Education topics and/or articles published occasionally in society's newsletters & 35 & 20 & $53^{\mathrm{a}}$ & ns \\
\hline Education topics and/or articles published regularly in society's newsletters & 38 & & & \\
\hline Education topics and/or articles published occasionally in society's research journals & 35 & 7 & 31 & ns \\
\hline Education topics and/or articles published regularly in society's research journals & 15 & 13 & 23 & ns \\
\hline Jointly sponsored textbook for undergraduates in the discipline & 0 & 7 & $15^{\mathrm{b}}$ & ns \\
\hline Society-sponsored textbook for undergraduates in the discipline & 8 & & & \\
\hline Other publishing practices & 19 & & & \\
\hline
\end{tabular}

ancludes societies that publish education articles either occasionally or regularly in society newsletters.

bIncludes societies that either jointly or individually sponsor textbooks for undergraduates. 


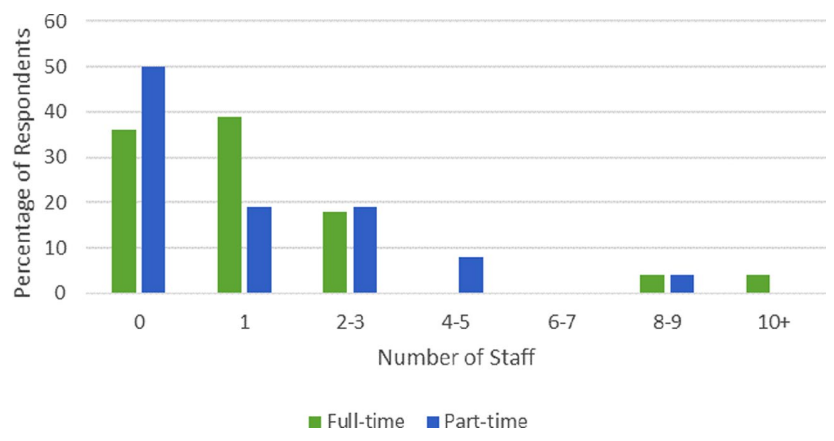

FIGURE 1. The survey asked responding societies to indicate how many full-time and part-time employees they had on staff who worked on educational programs and activities. Note that three of the societies that said they had one full-time staff member working on education indicated that that person did not spend $100 \%$ of his/ her time on educational programs and activities. The mean number of full-time employees working on educational programs was 1.5 per society and the mean number of part-time employees working on educational programs was 1.3 per society.

indicated there had been a decrease in the number of full-time staff working on education initiatives since 2008. In 2014, nearly two-thirds of the responding LSPS indicated they had full-time staff dedicated to education initiatives (Figure 1). Half of the LSPS indicated they had part-time staff working on education projects. The majority of LSPS had between one and three full-time staff members dedicated to education issues; very few had five or more full-time staff members in this role. Similarly, nearly $40 \%$ of the responding LSPS had one to three part-time staff members working on education programs. On average, the responding LSPS had 1.5 full-time staff members and 1.3 part-time staff members working primarily or exclusively on education issues. This does not indicate whether staff members were supported by internal or external funding sources. It should also be noted that a small number of responding LSPS (e.g., Human Anatomy and Physiology Society, National Association of Biology Teachers, Partnership for Undergraduate Life Science Education, and Project Kaleidoscope) are science education LSPS with a primary focus on education.

In 2014, most LSPS (67\%) indicated their budgets support undergraduate education initiatives. The large majority (82\%) said they supported their education programs at least in part by revenue generated from non-education related activities, including membership, subscriptions, registrations, and other fees (Supplemental Table S3). Most (57\%) receive external sources of funding such as grants and contracts to support educational activities. Nearly half received funding from either the society's strategic reserves (46\%) or revenue generated by education programs or activities (43\%). Most longitudinal comparison group LSPS (69\%) said they had some combination of internal and/or external support for undergraduate activities in 2008. By 2014, 92\% of longitudinal comparison group LSPS had internal support for undergraduate activities, and 58\% had both internal and external funding sources. There was significant growth between 2008 and 2014 in the longitudinal comparison group's use of their strategic reserves to support education initiatives. Only one life science professional society indicated that this was a source of funding for education initiatives in 2008, but more than half indicated that it was a source of funding in 2014 ( $p=0.014)$.

In $2014,30 \%$ of the responding LSPS had an annual education budget of more than $\$ 250,000$. An additional 30\% had budgets ranging from $\$ 51,000$ to $\$ 250,000$ and only $26 \%$ spent $\$ 50,000$ or less on their education programs (Supplemental Table S4). Notably, $15 \%$ of those responding were not aware of what their societies' total annual budgets for education were in 2014. LSPS also indicated the percentage of their societies' annual budgets allocated to educational programs. For nearly half of the LSPS, the education budget accounted for $<10 \%$ of the annual budgets, and for an additional $21 \%$, the education budget accounted for 10-19\%. For a smaller number of LSPS (8\%), educational activities account for $70 \%$ or more of the society budget; these were primarily the science education societies noted earlier.

Most of the 2014 responding LSPS (76\%) have formal educational collaborations/coalitions with other societies, and $48 \%$ have formal collaborations with other organizations such as museums, community-based organizations, and foundations (Supplemental Table S5). They also commonly sponsor presentations with other societies or at other society meetings (67\%). Most (52\%) also engage in outreach to the international community on undergraduate education initiatives. LSPS are less likely to sponsor memberships with other societies for undergraduate faculty $(24 \%)$ or students $(5 \%)$.

\section{Program Evaluation and Dissemination}

Traditionally, society programs are developed in response to a need perceived by the organizational leadership. For example, a drop in graduate student attendance at meetings may lead to reduced registration fees or increases in travel support awards. Programs are seldom the result of extensive need assessments, and publications about LSPS programs, awards, and initiatives tend to be descriptive articles in newsletters rather than studies in peer-reviewed journals. Furthermore, unless funded by an external source such as NSF or the National Institutes of Health, requirements for regular or rigorous program evaluation are dependent upon the specific LSPS. On the 2014 survey, LSPS responded to a series of questions on how they evaluate their undergraduate education programs and initiatives. Nearly onethird $(32 \%)$ of undergraduate programs or activities do not have specific goals and documented outcomes or measurable objectives to guide program evaluation (Supplemental Table S6). An additional 30\% of respondents indicated that less than half of their undergraduate programs or activities have specific goals and measurable objectives. Only $25 \%$ of responding LSPS said that $75 \%$ or more of their programs have evaluations guided by goals and objectives.

When asked about the program evaluation designs they use, most LSPS (62\%) said they use only an exit survey (Supplemental Table S7). One-third of LSPS (34\%) use time-series assessment such as pre-, post-, and follow-up surveys of participants. One society used a quasi-experimental design with a comparison group, and none of the responding LSPS use randomized study designs. In terms of evaluation instruments, most LSPS use surveys with multiple-choice (70\%) and/or open-ended (63\%) questions to monitor and evaluate their undergraduate programs or activities (Supplemental Table S8). 
They use records and products (41\%), interviews and focus groups (41\%), online discussion and direct observation (26\%), and tests/quizzes (15\%) to a lesser extent. Only 30\% use an external evaluation consultant, and 19\% use committee review as their external evaluation method. Based on the responses to these questions, it appears that $15-20 \%$ of responding LSPS do not formally evaluate some or all of their educational programs.

When asked how they disseminate the results of their program evaluations, most (56\%) indicated that their societysponsored Web page or blogs serve as a distribution method (Supplemental Table S9). Sessions at society (44\%) and other (30\%) meetings, nonscholarly publications (37\%), and social media (30\%) were also commonly used methods. Peerreviewed scholarly publications accounted for only $11 \%$ of responses.

\section{DISCUSSION}

LSPS promoting V\&C initiatives is an important indicator for measuring the impact of V\&C. While we did not measure a causative relationship between V\&C initiatives and LSPS responses, our study found that the growth of LSPS undergraduate initiatives has both paralleled the V\&C initiative and is aligned with Vision and Change report recommendations. In the 5 years since the initial Call to Action report (AAAS, 2010), LSPS increased their emphasis on undergraduate education via multiple mechanisms, contributing to the recognition and adoption of V\&C principles.

\section{Meeting the V\&C Calls for Action}

Concepts, Competencies, and Aligned Educational Materials. LSPS help establish and disseminate training standards for new professionals in their fields and often identify knowledge and skills required for proficiency. The Vision and Change reports encouraged LSPS to establish these standards for undergraduate education. We found that LSPS often develop undergraduate curricular guidelines and resources and serve as long-term knowledge caretakers by publishing new research and providing access to past research. We also found that LSPS "develop and steward" educational materials, serve as repositories for content knowledge, and maintain contact with educators by providing free access to content materials, as recommended by the Vision and Change reports. Interestingly, many of the LSPS "digital libraries" developed into "online learning and networking communities for undergraduate faculty" by 2014. Communities provide opportunities to give and receive advice, share effective teaching practices, and build collaborations and networks (Wenger et al., 2002; Wenger-Trayner and WengerTrayner, 2015); this was another V\&C suggestion (AAAS, 2015b). Therefore, LSPS serve as both knowledge stewards and online "homes" for growing educator networks.

Promotion of the Scholarship of Teaching and Learning (SOTL). Traditionally, disciplinary societies focus on scholarship in their scientific fields. However, we found that LSPS increasingly are recognizing the importance of teaching with respect to the future of their fields. They are publishing peer-reviewed education journals and/or education articles in their scientific research journals, including sessions on effective teaching methods and teaching scholarship at their scientific meetings and satellite workshops, and providing society awards for educational innovation and excellence as recommended by the Vision and Change reports (AAAS, 2010, 2011b, 2015b). This can be a transformative change for many fields in which teaching was not previously valued, and bench researchers were unaware of the field of education research.

Development of Undergraduate Educators. Recognizing that faculty members are critical to reform efforts, Vision and Change reports call on LSPS to provide professional development opportunities in teaching methods, SOTL, and leadership. We found that LSPS are addressing these issues through undergraduate faculty fellowships, workshops, online learning and networking communities, outreach and information through social media, and publishing education research and articles. While not all LSPS do all activities, most LSPS commit resources to engage and develop undergraduate educators. Similarly, LSPS were encouraged to make membership and resources more accessible to undergraduate educators. We found that very few LSPS offer discounted memberships for faculty involved in teaching, because this group often represents a large segment of their memberships, but many offer discounted memberships for future faculty (trainees). Most engage undergraduate faculty in LSPS governance and committees; therefore, undergraduate faculty play key roles in setting LSPS priorities and policies.

Development of Undergraduate Students. LSPS play an important role in both the training and professional socialization of future professionals (National Academy of Sciences, National Academy of Engineering, and Institute of Medicine, 2011). Undergraduate students are not only future members but represent the future of a society's scientific field. LSPS are highly motivated to attract undergraduate students to their fields and promote outstanding education for them. LSPS also provide "professional socialization," involving students in society activities early in their training. While LSPS cannot fill the critical one-on-one mentoring roles of advisors, they make important contributions to both the psychosocial and career mentoring activities in which a trainee engages. Psychosocial mentoring activities enhance students' "sense of self and their social relation with their environment" (Davidson and Foster-Johnson, 2001, p. 551). The Vision and Change reports called for LSPS to increase undergraduate student involvement by offering undergraduate memberships and welcoming undergraduate students to scientific meetings to present their research and attend special workshops designed for them. We found that many LSPS offer undergraduate memberships and meeting travel awards. At meetings, undergraduate students present their research, network with other students and scientists in the field, and attend career development workshops. Increasingly, undergraduate students attending the meetings present research supported by LSPS-sponsored undergraduate research fellowships. Similarly, undergraduate students on campus engage in LSPS-sponsored student clubs or chapters. Each life science professional society has specific programs to engage undergraduate students, but collectively, they provide a wealth of programs for the professional socialization of undergraduate students in life science fields. 
Society Collaborations. Finally, the Vision and Change reports encouraged LSPS to collaborate on undergraduate education reform initiatives, even proposing a biennial summit meeting for LSPS on undergraduate education (AAAS, 2010, 2015b). While life science fields do not have one overarching professional society, collaborations among groups of societies are common. Our study indicates that the large majority of LSPS participate in both formal and informal collaborations and coalitions with other societies and/or other organizations, including international organizations. PSALSE convenes regular meetings of LSPS representatives from the Washington, DC, area and around the United States.

\section{Supporting Change}

We found that many LSPS have made undergraduate education, educators, and students a priority in the period since the V\&C call to action. Although the present study did not identify $\mathrm{V} \& \mathrm{C}$ as the specific change agent, the substantive increases in undergraduate efforts by LSPS undoubtedly have contributed to the changes documented in the 2015 report Vision and Change: Chronicling Change, Inspiring the Future. The efforts of LSPS to legitimize undergraduate education research and increase the visibility and importance of teaching also include changes in initiatives and policies that reveal an ongoing dedication to changing undergraduate life science education. In fact, nearly half of the responding LSPS address undergraduate education explicitly in their missions or strategic plans.

Staffing and Funding. The programs and initiatives described here require staff, volunteers, and financial resources. Nearly all LSPS in our study have paid staff with an exclusive or partial focus on education and a volunteer committee chair. We found that LSPS education staffs are growing but are still very small, with many programs managed by a single staff member or volunteer. Considering the array of educational efforts documented by the survey, the staffing levels may be insufficient to both manage and thoroughly evaluate each program. This is an issue that LSPS governing boards will need to address. Volunteer leadership can provide guidance and perspective, but quality programming requires professional staffing for consistency and ongoing impact.

How do LSPS pay for their educational efforts, and how much do they spend? Programs are rarely fee based. Nearly all use revenue generated through other activities (e.g., meetings, membership, and journal subscription fees), external grants or contracts, and, increasingly, funds from strategic reserves. This last is especially noteworthy, since the study period included the 2008-2009 stock market drops that significantly impacted many nonprofit reserves (Blair, 2008). For most LSPS, the education budget comprises $<20 \%$ of the overall society budget. In sum, LSPS commit both staff time and funds, including reserves, to educational efforts. As LSPS face new economic realities such as shrinking subscriptions and meeting attendance, governing boards must identify how educational efforts benefit the field and set funding priorities for those efforts.

Documenting Impacts and Sharing Findings. Just as educators are being increasingly called to engage in both evidence-based teaching and education research, those who manage educational programs are being called to publish their evaluation results in peer-reviewed journals (NSF, 2014). This requires well-designed evaluation plans; effective measurement instruments; and staff with evaluation and/or education research knowledge, analytical skills, and writing skills to prepare manuscripts for peer-reviewed publications. We found that LSPS, like educators, are still working to build these capacities. Very few LSPS have specific goals, measurable objectives, and robust evaluation designs for their undergraduate programs. While LSPS are adept at publishing and disseminating peer-reviewed scientific research, they rarely do so with the evaluation results from their own programs. The reasons for this are not clear from the current study, but discussions with the PSALSE group suggest that lack of evaluation and publication expertise and lower priority for developing evaluation manuscripts are contributing factors.

\section{CONCLUSIONS}

Many LSPS are extensively engaged in undergraduate education in their fields, setting standards for their disciplines, providing vetted education resources, engaging undergraduate students in both research and education, and enhancing both professional development and recognition/status for educators. They devote funding and staff to these efforts and engage volunteer leadership. There has been a notable expansion of undergraduate efforts in many areas during the time frame of the V\&C initiative. Furthermore, these indicators can serve as a baseline for defining, aligning, and measuring how LSPS can promote sustainable, evidence-based support of life science undergraduate education initiatives.

\section{Future Directions}

It is important to recognize that LSPS committees and governing boards are ultimately responsible for setting priorities and allocating resources for their organizations' activities. They must consider factors such as the membership size and geographic distribution, income sources and financial reserves, strategic priorities, and changes in the discipline. As each society reports and comments on our findings, the study will increase awareness about the initiatives of the LSPS and affirm the common goal of improving undergraduate teaching and learning. Because the survey results are tied to the specific initiatives suggested in V\&C, LSPS can use the findings internally to identify potential areas of growth. In addition, the findings may promote discussions of program staffing. Staff and volunteers must be strategically structured so that programs can be developed and evaluated for long-term impact. On the basis of the study findings and ongoing PSALSE discussions, we have identified several actions for consideration by LSPS:

- Collaborations for faculty development: LSPS should identify and share effective professional development models and collaborate to offer expanded offerings on topics such as SOTL, discipline-based education research, and evidence-based teaching. PSALSE provides a promising mechanism to establish collaborations for faculty development.

- Engaging undergraduate students: Models for professional socialization and engagement of undergraduate 
students should also be shared, particularly for activities conducted at annual meetings or online. This is another area in which PSALSE can facilitate collaborations.

- Funding models: Survey results indicate that most educational offerings are supported by other sources of society income. Sharing funding and resource-allocation models and writing collaborative grants to support multisociety programs are promising ways to support new or expanded programs. PSALSE also is interested in gathering additional information on externally funded program models and resources that can be shared with LSPS.

- Program evaluation: We found that LSPS are not consistently and thoroughly evaluating their programs and efforts and sharing their findings. There is a clear need for professional development and resource allocation to assure that appropriate formative and summative evaluations are conducted and that results are analyzed, used to improve the programs/efforts, and shared with other societies. PSALSE is discussing developing a collaborative resource collection and professional development on evaluation design, implementation, and analysis, as well as cross-society evaluation methods.

- Future PSALSE surveys: The results of these initial surveys of LSPS highlight the usefulness of gathering additional information in the future. The PSALSE group is discussing plans for future surveys to document programs in more detail, including numbers of participants and awardees in programs, specifics on grant-funded projects, and an analysis of critical programs and gaps in programming.

\section{Collaboration as Cornerstone}

Many of the actions above are collaborative, with LSPS sharing their strengths and experiences toward improved undergraduate education in all of the life science fields. As described earlier, organizations such as PSALSE offer tremendous opportunities to launch these collaborative efforts and to share models and outcomes. LSPS clearly have an important role to play in improving undergraduate life science education. Activities, programs, and initiatives that capitalize on the strengths of a specific society and the needs of its life science field, that are grounded in previous research, that have specific objectives and a coordinated evaluation plan, and that are effectively communicated both to the field and the wider scientific communities have the greatest potential for broad and lasting impacts.

\section{ACKNOWLEDGMENTS}

We thank the following: Teresa Mourad, Ecological Society of America, for her insightful review and editing of earlier versions of the article; Shirley Malcom and Yolanda George, American Association for the Advancement of Science, for both promoting the role of professional societies in V\&C and sharing the data from the initial society surveys; and the staff and members participating in the PSALSE for offering suggestions and participating in the follow-up survey. We also thank the NSF for their support of the V\&C programs which provided the initial professional society data and the Vision and Change reports.

\section{REFERENCES}

American Association for the Advancement of Science (AAAS) (2009). Vision and Change in Undergraduate Biology Education: Preliminary Reports of Conversations, Washington, DC.

AAAS (2010). Vision and Change: A Call to Action-A Summary of Recommendations, Washington, DC

AAAS (2011a). BioSciEd Net Digital Library Portal for Teaching and Learning in the Biological Sciences, Washington, DC. www.biosciednet .org/portal (accessed 10 January 2016).

AAAS (2011b). Vision and Change in Undergraduate Biology Education: A Call to Action, Washington, DC.

AAAS (2015a). AAAS Affiliates page. www.aaas.org/aaas-affiliates (accessed 10 January 2016)

AAAS (2015b). Vision and Change in Undergraduate Biology Education: Chronicling Change, Inspiring the Future, Washington, DC.

American Association of Physics Teachers (2013). The Role of Scientific Societies in STEM Faculty Workshops, College Park, MD.

American Society for Engineering Education (2013). Transforming Undergraduate Education in Engineering-Phase I: Synthesizing and Integrating Industry Perspectives, Washington, DC.

Blair E (2008). Assessing impact of financial crisis on nonprofits. NPR. www.npr .org/templates/story/story.php?storyld=95222990 (accessed 10 January 2016).

Davidson MN, Foster-Johnson L (2001). Mentoring in the preparation of graduate researchers of color. Rev Educ Res 71, 549-574.

Hilborn RC, Howes RH, Krane KS (2003). Strategic Programs for Innovations in Undergraduate Physics: Project Report, College Park, MD: American Association of Physics Teachers.

Macdonald HR, Manduca CA, Mogk DW, Tewksbury BJ (2004). On the cutting edge: improving learning by enhancing teaching in the geosciences. In: Inventions and Impact 2: Building Excellence in Undergraduate Science, Technology, Engineering, and Mathematics (STEM) Education, Washington, DC: American Association for the Advancement of Science, 233-240.

Matyas ML (2008). Vision and change: perspectives and proposed actions from scientific societies. In: Vision and Change in Undergraduate Biology Education: Preliminary Reports of Conversations, Washington, DC: American Association for the Advancement of Science, 22-38.

McDonald JH (2014). Handbook of Biological Statistics, 3rd ed., Baltimore, MD: Sparky House.

Mercier S (2015). Food and Agriculture Education in the United States, Washington, DC: AGree.

Musante S, Potter S (2012). What is important to biological societies at the start of the twenty-first century? BioScience 62, 329-335.

National Academy of Sciences, National Academy of Engineering, and Institute of Medicine (2007). Rising above the Gathering Storm: Energizing and Employing America for a Brighter Economic Future, Washington, DC: National Academies Press.

National Academy of Sciences, National Academy of Engineering, and Institute of Medicine (2010). Rising above the Gathering Storm, Revisited: Rapidly Approaching Category 5, Washington, DC: National Academies Press.

National Academy of Sciences, National Academy of Engineering, and Institute of Medicine (2011). Expanding Underrepresented Minority Participation: America's Science and Technology Talent at the Crossroads, Washington, DC: National Academies Press.

National Academy of Sciences, National Academy of Engineering, and Institute of Medicine (2014). The Postdoctoral Experience Revisited, Washington, DC: National Academies Press, 122

National Research Council (2003). BIO2010: Transforming Undergraduate Education for Future Research Biologists, Washington, DC: National Academies Press.

National Science Foundation (2014). Frequently Asked Questions (FAQs) for Improving Undergraduate STEM Education (IUSE), Arlington, VA. WwW .nsf.gov/pubs/2014/nsf14023/nsf14023.pdf (accessed 10 January 2016).

Next Generation Science Standards (2013). Critical Stakeholders page www.nextgenscience.org/critical-stakeholders (accessed 10 January 2016). 
President's Council of Advisors on Science and Technology (2012) Engage to Excel: Producing One Million Additional College Graduates with Degrees in Science, Technology, Engineering and Mathematics, Washington, DC: U.S. Government Office of Science and Technology.

Project Kaleidoscope (2015). DSEA-Disciplinary Society and Education Association Alliance, Washington, DC. www.pkal.org/documents/DSEA.cfm (accessed 10 January 2016).

Sawyer K, Alper J (2014). Undergraduate Chemistry Education: A Workshop Summary, Washington, DC: National Academies Press.

Singer SR, Nielsen NR, Schweingruber HA (2012). Discipline-Based Education Research: Understanding and Improving Learning in Undergraduate Science and Engineering, Washington, DC: National Academies Press.

Survey Monkey (2015). Survey Monkey home page. Palo Alto, CA. www surveymonkey.com (accessed 3 November 2015).
U.S. Department of Health and Human Services (2016). Chart 1: Is an Activity Research Involving Human Subjects? www.hhs.gov/ohrp/sites/default/ files/full-2016-decision-charts.pdf (accessed 10 January 2016).

Wei C, Fry C, Boylan M (2012). Undergraduate biology education. In: Leadership in Science and Technology: A Reference Handbook, vol. 2, ed. WS Bainbridge, Thousand Oaks, CA: Sage, 878-885.

Weidman JC, Twale DJ, Stein EL (2001). Socialization of Graduate and Professional Students in Higher Education: A Perilous Passage, ASHE-ERIC Higher Education Report 28, Washington, DC: Association for the Study of Higher Education.

Wenger E, McDermott RA, Snyder W (2002). Cultivating Communities of Practice: A Guide to Managing Knowledge, Boston, MA: Harvard Business Publishing.

Wenger-Trayner E, Wenger-Trayner B (2015). Introduction to communities of practice. http://wenger-trayner.com/introduction-to-communities -of-practice/ (accessed 30 December 2016). 